\title{
EFFECTS OF PUBERTY ON JUMP AND SPRINT PERFORMANCE IN YOUNG FUTSAL PLAYERS
}

EFEITOS DA PUBERDADENO DESEMPENHO DE SALTOS E SPRINTS EM JOGADORES JOVENS DE FUTSAL EFECTOS DE LA PUBERTAD EN EL DESEMPEÑO DE SALTOS Y SPRINTS EN JUGADORES JÓVENES DE FUTSAL

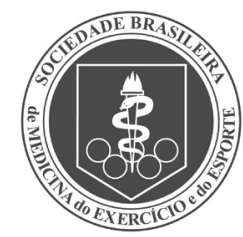

ReView Article

ARTIGO DE REVISÃO ARtículo de REVISIÓN
Poliane Dutra Alvares ${ }^{1}$ (D) (Physical Education Professional) Paula Júlia Chaves ${ }^{2}$ (ID (Physical Education Professional) Mário Norberto Sevilio de Oliveira Junior ${ }^{3}$ (ID

(Physical Education Professional) Túlio Luiz Banja Fernandes ${ }^{4}$ (DD (Physical Education Professional)

Christiano Eduardo Veneroso 3 (ID) (Physical Education Professional) Christian Emmanuel Torres Cabido 3 (iD) (Physical Education Professional)

1. Universidade Federal do Maranhão (UFMA), Pitágoras Faculty, São Luís, MA, Brazil. 2. Universidade Federal do Maranhão (UFM), São Luís, MA, Brazil.

3. Universidade Federal do Maranhão (UFMA), Postgraduate Program in Physical Education, Department of Physical Education, São Luís, MA, Brazil.

4. Universidade Federal do Ceará (UFC), Instituto de Educação Física e Esportes (UFC), Fortaleza, CE, Brazil.

\section{Correspondence:}

Poliane Dutra Alvares

Rua Nascimento de Moraes, Casa 11-a, São Francisco, São Luís, MA, Brazil. 65076-320.

polianealvares87@gmail.com

\section{ABSTRACT}

Futsal is a sport that involves motor actions with high intensity and short duration, especially vertical jumps and sprints, which require fast application of strength and speed. The evaluation and training of these physical capacities is a routine practice of coaches, especially in the base categories, which are the entry point for many children and adolescents aiming for a professional career in futsal. With regard to the training of this public, puberty is a factor that must be considered, as a natural biological process involving several bodily transformations that can influence the performance of these physical capacities, especially considering that the categories are divided by chronological age, which does not always correspond to pubertal age. The objective of this study was to conduct a literature review of body modifications during puberty, and how these can affect the aspects that determine good performance in jumps and sprints. It was verified that this phase is associated with hormonal changes, an increase in muscle mass, and anthropometric aspects, as well as the maturation of the neuromuscular functions and refinement of the more complex motor activities, such as locomotion. Together, these factors can favor the fast application of force, and better performance of these players in terms of motor activities. However, it is important to emphasize that although these factors increase and naturally favor the players' performance in terms of strength and speed, it is a phase in which specific types of training focused on the aspects that determine good performance are fundamental to increase these capacities and diminish other aspects that also occur with the bodily development, such as a transient decrease in motor coordination and balance due to the rapid growth spurt, and tissue stiffness, which can sometimes occur during this period. Level of evidence V; Expert Opinion.

Keywords: Puberty; Muscle strength; Physical performance.

\section{RESUMO}

O futsaléum esporte que envolve ações motoras de alta intensidade e curta duração, principalmente, saltos verticais e sprints que exigem rápida aplicação de força e velocidade. A avaliação e o treinamento dessas capacidades físicas fazem parte de uma prática rotineira de treinadores, especialmente, das categorias de base, em que há o ingresso de muitas crianças e adolescentes que pretendem seguir uma carreira profissional no futsal. Em relação ao treinamento desse público, a puberdade é um fator que deve ser considerado como um processo biológico natural envolvendo diversas transformações corporais que podem influenciar no desempenho dessas capacidades físicas, principalmente, considerando que as categorias são divididas pela idade cronológica que nem sempre corresponde à idade puberal. O objetivo desse estudo consistiu em realizar uma revisão da literatura em relação às modificações corporais durante a puberdade e como as mesmas podem afetar os aspectos que determinam o bom desempenho em saltos e sprints. Foi verificado que essa fase está associada a alterações hormonais, aumento da massa musculare aspectos antropométricos, assim como o amadurecimento das funções neuromusculares e refinamento das atividades motoras mais complexas como a locomoção. Juntos, esses fatores podem favorecer a rápida aplicação de força e maior rendimento desses jogadores quanto às atividades motoras. Entretanto, éimportante ressaltar que, embora esses fatores aumentem e favoreçam naturalmente o desempenho de força e velocidade dos jogadores, essa é uma fase em que tipos específicos de treinamento focados em aspectos que determinam o bom rendimento são fundamentais para aumentar essas capacidades e diminuir outros aspectos que também podem ocorrer com o desenvolvimento corporal, como por exemplo, a diminuição temporária da coordenação motora e equilíbrio devido ao pico de crescimento e a rigidez tecidual que, algumas vezes, podem ocorrer durante esse período. Nível de evidência V; Opinião de Especialista.

Descritores: Puberdade; Força muscular; Desempenho físico.

\section{RESUMEN}

El futsal es un deporte que abarca acciones motoras de alta intensidad y corta duración, principalmente, saltos verticales y sprints, que exigen rápida aplicación de fuerza y velocidad. La evaluación y entrenamiento de estas capacidades físicas forman parte de una práctica rutinaria de entrenadores, especialmente de las categorías de base, en que hay ingreso de muchos niños y adolescentes que pretenden seguir una carrera profesional en el futsal. Con relación al entrenamiento de ese público, la pubertad es un factor que debe ser considerado como un proceso biológico natural involucrando diversas transformaciones corporales que pueden influenciar en el desempeño de esas capacidades físicas, principalmente, considerando que las categorías son divididas por la edad cronológica que no 
siempre corresponde a la edad puberal. El objetivo de este estudio consistió en realizar una revisión de la literatura con relación a las modificaciones corporales durante la pubertad y cómo pueden las mismas afectar los aspectos que determinan el buen desempeño en saltos y sprints. Se verificó que esta fase está asociada a alteraciones hormonales, aumento de la masa musculary aspectos antropométricos, asi como la madurez de las funciones neuromuscularesy refinamiento de las actividades motoras más complejas como la locomoción. Juntos, estos factores pueden favorecer la rápida aplicación de fuerza y mayor rendimiento de estos jugadores cuanto a las actividades motoras. Entretanto, es importante resaltar que, aunque estos factores aumenten y favorezcan naturalmente el desempeño de fuerza y velocidad de los jugadores, esta es una fase en que tipos específicos de entrenamiento enfocados en aspectos que determinan el buen rendimiento son fundamentales para aumentar esas capacidades y disminuir otros aspectos que también pueden ocurrir con el desarrollo corporal, como por ejemplo, la disminución transitoria de la coordinación motora y el equilibrio debido al pico de crecimiento, además de la rigidez tisular que, algunas veces, pueden ocurrir durante ese período. Nivel de evidencia V; Opinión de Especialista.

Descriptores: Pubertad; Fuerza muscular; Desempeño físico.

\section{INTRODUCTION}

Futsal is an intermittent sport, with the highest percentage of frequent and decisive high-intensity and short-term playing actions, called straight line sprints (SLS). Other tasks include change of direction sprints (CODS) and movements such as kicks and jumps. ${ }^{1}$ These tasks depend mainly on strength and speed as fundamental physical capabilities for success in these movements. ${ }^{1}$ The player who has a high ability to build muscle fibre, neuromuscular coordination and use potential elastic energy (PEE), in addition to motor coordination and developed body balance, can present better performance and positional advantages over the opponent, with efficient scoring and anticipation in decisive play. ${ }^{2,3}$

For this reason, the search for better performance in modalities that require this characteristic, such as futsal, has made the evaluation of these physical capacities fundamental to guide athletes' training, aiming to improve the players' performance on court, 3,4 especially in young athletes. The number of children and adolescents involved with the sport is growing steadily in Brazil, and many of these start in sports schools aiming at a professional career in the sport, which is why systematic training has become a requirement to develop these players' performance. ${ }^{5}$

Regarding the responses to training in young athletes, one factor to consider is the process of puberty that affects these individuals. Puberty is a period in which morphological growth and changes in the body's functional characteristics are intense and rapid. ${ }^{6}$ During puberty, neural functions mature, testosterone and growth hormone production increases, ${ }^{8}$ and anthropometric aspects ${ }^{9}$ and muscle mass develop. ${ }^{10}$ Considering that these factors, closely linked to the puberty process, directly affect the production of force ${ }^{11}$ and velocity, ${ }^{12}$ it is believed that they can interfere with sports motor movements such as the performance of jumps and sprints in this phase, ${ }^{13}$ tasks frequently performed in sports modalities that present high demands of power output and speed performance, such as futsal.'

In the sports context, players are grouped by chronological age, ${ }^{14}$ which does not necessarily correspond to the same pubertal stage. This makes it common to find athletes at different stages of puberty, which can directly influence performance of the sport's specific motor movements, within the same basic category. ${ }^{13}$ To the best of our knowledge, studies demonstrating the effects of puberty on the motor actions present in futsal are scarce. Such an analysis would need to consider that major body transformations during puberty result in changes in strength and speed performance. ${ }^{15}$ Thus, the aim of the present study is to verify through a literature review how changes resulting from puberty may be reflected in the performance of jumps and sprints in players in young futsal players.

\section{Futsal and game characteristics}

among indoor sports, futsal is one of those with the highest participation and popularity. ${ }^{16}$ Official matches take place on a 40x20m court with a play duration of 40 minutes divided into two 20 minute periods. ${ }^{17}$ The evolution of different aspects of futsal (rules, physical demands, tactics, etc.) has seen athletes' preparation undergo changes in order to meet the new demands imposed by the game. ${ }^{18}$ In futsal, the main characteristics of actions are short-term intense physical efforts, with an emphasis mainly on physical strength and speed, such as kicks, jumps and sprints, tasks that differentiate athletes with the best performance during a game. ${ }^{1}$

SLS represent up to 11 per cent of this distance in runs of up to $20 \mathrm{~m}$, with speeds over $18.3 \mathrm{~km}_{*} \mathrm{~h}^{-1}$. CODS are present in 74 per cent of the game actions, ${ }^{17,19}$ along with vertical jumps which, as well as sprint performance, require the futsal athlete to produce force more quickly. ${ }^{18}$ Although these values refer to the adult category, it is possible that this behaviour is similar in the basic categories. Many players start in the grassroots category during adolescence, aiming at a professional career in the sport and to stand out early in competitions, ${ }^{5}$ which stimulates the improvement of physical skills through systematic training, aiming to improve the performance of these athletes. ${ }^{3,4}$

Regarding these players'response to training, one factor to consider during adolescence is the pubertal process that affects these individuals. In the sports context, the players are grouped into categories by chronological age with two years in each group. ${ }^{14}$ Considering that the age of the individual does not necessarily correspond with the pubertal stage, this suggests that individuals in different pubertal stages within a category may present different performances in the specific motor movements of the modality, and that prepubertal individuals do not necessarily present a lack of ability in the sport., ${ }^{8,20}$

\section{Jump performance}

in the sports context, vertical jumping tests are widely used for training ${ }^{21,22}$ and evaluation of muscle strength and lower limb power through the jumping height reached, the squat jump (SJ) and counter-movement jump (CMJ) being the main vertical tests used in the literature. ${ }^{21-25}$ Vertical jumps involve lower limb actions at maximum effort intensity in a short time interval for force generation. ${ }^{26,27} \mathrm{SJ}$ and CMJ execution techniques are widely described according to the standardizations initially proposed by Komi and BosCO $^{28}$ and commonly adopted in other studies. ${ }^{21-25}$

During both jumps (SJ and CMJ), the subject, with hands on the hips and head up looking forward, makes the last contact (take off) and the beginning of the landing (first contact) with the toes; during 
the flight phase, the knees are kept at $180^{\circ}$ (fully extended). ${ }^{28}$ In SJ, the subject performs the movement from a static semi-squat position with flexed knees, hips at an angle of approximately $90^{\circ}$ and an erect trunk, a position in which he remains for about three seconds. He then begins the ascending phase until he loses contact with the ground, starting the flight phase. In CMJ, the technique is the same except for the initial position. In this jump, the subject starts from a standing position and from there, performs a counter-movement until reaching the lowest point of the body's centre of gravity (descending phase), followed by an immediate extension of the lower limb joints to start the ascending phase, until losing contact with the ground, starting the flight phase. ${ }^{28}$ In the evaluation of jumps using instruments that measure flight time, the height reached is estimated by the equation jump height $=1 / 8 * g * t^{2}$, where $g$ is the acceleration of gravity $\left(9.81 \mathrm{~m}_{*} \mathrm{~s}^{-2}\right)$ and $t$ is the flight time $(\mathrm{s}){ }^{2.9}$

Performance in $\mathrm{S} J$ is mainly dependent on the neural recruitment capacity and the number of activated fibres in the time available for force production, factors that also influence maximal strength. ${ }^{11}$ On the other hand, during CMJ, due to the fast transition between the phases (descending and ascending) and the high force production in short time intervals, a mechanism known as the stretching-shortening cycle (SSC) is verified. ${ }^{30}$ SSC is a mechanism originated from movements involving stretching immediately followed by shortening of the tissue - downward and upward phases of the CMJ, respectively. These SSC characteristics contribute to the power output in CMJ during the vertical thrust phase. SSC's contribution to performance can be classified according to the time available for force production (contact time), either short (<250ms) or long ( $>250 \mathrm{~ms}) .^{30}$

Although there are other mechanisms that are responsible for the higher performance of SSC, ${ }_{1}^{31}$ the storage and use of PEE by passive muscle structures due to deformation of this tissue during stretching (downward phase) is widely accepted as the main explanation for better movement efficiency. ${ }^{31}$ During the upward phase, the PEE previously stored in the downward phase causes a spontaneous retraction of the fibre to its initial length, increasing force production and favouring the jump propulsion phase. ${ }^{32}$ Vertical jumps, in addition to being used as a means of assessing lower limb force, have also been used as a component of physical fitness in sport for the performance of actions involving rapid force production, such as sprint-mediated performance. ${ }^{33}$ This is commonly presented in the literature looking at performances such as joint and muscle movement patterns, ${ }^{27}$ the ATP-CP27 power supply system, higher nerve conduction velocity, ${ }^{34}$ and storage and use of PEE. ${ }^{35}$

\section{Sprint performance}

Displacement velocity, commonly referred to as sprint, is the individual's ability to run faster and coordinate cyclic movements. ${ }^{12}$ This is a series of movements in which each lower limb performs the support phase (foot contact with the ground) and balance (no foot contact with the ground). ${ }^{12}$ During the run, the stride is the cycle of movement in which a foot touches the ground, loses contact, and then the same foot touches the ground again. Thus, when the individual's goal is to move as quickly as possible from one point to another, the high frequency at which this cycle occurs requires a highly synchronized pattern between the lower limbs. ${ }^{36}$

One way to evaluate speed is the SLS, where the individual must travel a certain distance in a straight line in the shortest possible time. This performance, kinematically, is determined by the product of stride length (range reached) and stride frequency (number of steps per second) over a given distance. ${ }^{12}$ Considering futsal, where most sprints are performed at distances close to $20 \mathrm{~m}$, this is the distance for the SLS test that has been adopted by different studies in this modality, 22,37 where the acceleration phase is observed in the first $10 \mathrm{~m} .{ }^{38}$ Given that during futsal matches it is common to perform high-speed offsets with direction changes, an individual's ability to accelerate, decelerate, change direction and accelerate again is commonly assessed in sprint testing involving change direction, ${ }^{39}$ the CODS.

Locomotion during running (SLS and CODS) depends on factors such as learning, which includes improved technique, motor control and balance during body mass displacement, ${ }^{12}$ and anthropometric aspects, such as height and length of lower limbs, that contribute to increased stride amplitude. ${ }^{40,41}$ Running ability also depends on rapid force production, inter- and intramuscular coordination, and muscle fibre recruitment ability. ${ }^{12,39-41}$ During the initial metres of the SLS (acceleration phase) and CODS (due to constant changes in direction), the lower velocity values result in longer ground contact time and, consequently, more time available for power generation. ${ }^{38}$ This feature means that, although not achieved, maximum strength contributes to increased performance. ${ }^{42}$

As speed increases during running, the time of the support phase is shorter compared to the swing phase, ${ }^{36}$ favouring the storage and utilization capacity of the PEE. This mechanism is present at the moment of rapid transition between the support phase and swing in the sprint, which contributes to the production of force at times of higher velocity and, consequently, shorter time of contact with the ground during running. ${ }^{42}$ The shorter contact time at high speeds also favours a higher explosive force (rate of force development) for performance. ${ }^{42}$

\section{Physical performance and puberty}

Growth, maturation and development are processes that are related to the human body. Growth is characterized by dimensional or quantitative biological aspects of the body, accomplished by multiplying or increasing the number of cells. ${ }^{20}$ Maturation can be defined as a qualitative biological phenomenon and expresses the maturation of the functions of different organs and systems. ${ }^{6}$ Development is related to a biological and behavioural context involving both processes mentioned above, added to by environmental stimuli (learning and experience). ${ }^{8}$ Puberty is the phase that comprises these three aspects and usually occurs around 10 to 12 years of age in girls and between 12 and 14 years in boys. ${ }^{8,20}$ This phase is associated with morphological ${ }^{11}$ and hormonal changes, ${ }^{8}$ higher neuromuscular organization, ${ }^{11}$ and refinement of more complex motor activities such as locomotion. ${ }^{20}$

Regarding neuroendocrine aspects, growth hormone $(\mathrm{GH})$ increases its range and the frequency of secretion at puberty, ${ }^{20}$ which coincides with the age of higher growth velocity, called peak height velocity (PHV). ${ }^{43,44}$ The action caused by the anabolic hormonal responses of $\mathrm{GH}$ during puberty contributes to accelerated longitudinal growth (reaching PHV of around 8 and $10 \mathrm{~cm}_{*}$ year $\left.^{-1}\right)_{1}{ }^{44}$ a phase in which the bone formation process overlaps the resorption process, benefiting increased bone mass and linear body increment. ${ }^{45}$ Testosterone is another hormone that has high production during puberty and contributes to an increase in protein synthesis in this phase, favouring an increase in muscle strength. ${ }^{46}$

For Gallahue, Ozmun and Goodway, ${ }^{20}$ the period corresponding to puberty encompasses characteristics at different levels that favour motor performance: the specialized level, from seven to ten years old, which is the transition period, with a combination of fundamental movements such as running and jumping, and different sports experiences; the level of application, between 11 and 13 years old, where there is improvement of the movements initiated in the transition stage, sports direction, and increased adaptations to training; and the level of utilization, the moment of maximization of capacities and of physical, psychological and tactical preparation, that occurs from around 14 years old in these players.

Pubertal individuals engaged in sports such as futsal may benefit from training adaptations and morphological modifications triggered by 
the natural physical maturation process. ${ }^{20}$ This context could mean that within the same group, or category, individuals who are already advanced in pubertal development will perform better than those in lower pubertal stages. In this scenario, it is of fundamental importance that coaches and physical trainers identify the pubertal stage of their athletes in order to know if the observed performance comes from training or puberty. Still, one can expect that these changes, in isolation, do not determine success within the sport, ${ }^{8}$ as some changes generated by puberty may also compromise performance, requiring coaches to know the stage each player is in and the impact of puberty on the determinants. ${ }^{2}$

The ability to run requires high motor performance which, besides being influenced by neuromuscular aspects, is also influenced by body characteristics (size and proportions). ${ }^{2,8,15}$ Hammammi et al., ${ }^{27}$ finding a moderate correlation $(r=-0.499 ; p<0.01)$ between CODS and the balance test in soccer players, point out that sprints involve a motor control ability and maintenance of body balance, factors that may undergo changes in the growth spurt phase, resulting in slight decreases in body coordination and balance. ${ }^{2,13,47}$

The moment of growth spurt, linear increase of the body, occurs primarily in the lower limbs compared to the upper limbs and trunk, and does not occur simultaneously with muscle growth, causing body disproportion and transient decreases in balance and motor coordination, directly affecting performance of speed due to body instability presented in the stride frequency during the development of running. $2,7,13,15$ Although it is understood that speed performance is the product of stride length and frequency, there is a scarcity of studies verifying the behaviour of these elements throughout adolescence and at specific pubertal stages. ${ }^{48}$ Despite this lack of information, it is plausible to propose the need for specific speed training, especially involving coordination exercises, balance and mobility, to improve physical capacity in young athletes. ${ }^{2}$

Muscle-tendon stiffness and physical performance during puberty is another little explored factor, considering that less rigid elastic tissues may influence the performance of CMJ and sprints. ${ }^{49,50}$ Laffaye et al. ${ }^{51}$ observe an increase in lower limb stiffness with increased chronological age (11 and 20 years old), similar to other studies. ${ }^{52-55}$ For Gajdosik, ${ }^{56}$ the increase in muscle mass indicates a greater amount of elastic tissue (passive tissues, such as endomysium, perimysium, epimysium and tendons) - that is, a larger area for storage of PEE. However, the increase in tendon thickness also implies an increase in the amount ${ }^{56}$ and size of collagen fibres, ${ }^{57}$ a structural and functional component of the tendons. These fibres have spiral structures that allow an exponentially stretching curved when exposed to a rapid application of external force that causes them to stretch, making the tissue more rigid ${ }^{56,57}$ and, consequently, hindering better responses in activities that use SSC, such as jump and sprint performance.

Therefore, if an increase in muscle mass can increase tendon-muscle stiffness, ${ }^{50}$ and considering that during puberty adolescents go through the process of muscle increase, ${ }^{8}$ it is possible that the increase in tissue stiffness observed in this phase ${ }^{51}$ is associated with this process. On the other hand, Kubo et al. ${ }^{58}$ found that young individuals with lower rigidity in the vastus lateralis muscle-tendon complex also had higher PEE storage and SSC performance, which is important during running and can be improved through adaptations to specific training, such as plyometric training..$^{59,60}$

Therefore, although puberty increases physical performance and influences motor tasks such as jumps and sprints widely present in sports such as futsal, it is essential that sports professionals know the influences of puberty on motor performance, paying attention to the need to evaluate the pubertal stage of athletes in young athletes. Such information will allow an adequate determination of the training need and load in the prescription of specific speed and strength exercises, such as plyometric training, capable of enhancing SSC ${ }^{59,60}$ performance.

\section{CONCLUSION}

Studies have shown a direct influence of puberty on the main determinants of jump and sprint performance. Because of this, players at different pubertal stages may perform differently from their equivalents, considering that players are grouped by chronological age, which does not always correspond to pubertal stage. We emphasize the importance of knowing the pubertal stage of each player, as well as its influence on changes in strength and speed. Further studies are needed to assist professionals working with young athletes, contributing to the organization of training, especially futsal-specific tasks and sprints, in young futsal players.

\section{ACKNOWLEDGMENT}

Conselho Nacional de Desenvolvimento Científico e Tecnológico (CNPq), Fundação de Amparo à Pesquisa e ao Desenvolvimento Científico e Tecnológico do Maranhão (FAPEMA), Rede de Supermercados Mateus and the research groups in Genetics and Sports (GENES) and Physical Exercise: Health and Human Performance (ExeF: SDH) from UFMA.

All authors declare no potential conflict of interest related to this article

AUTHORS' CONTRIBUTIONS: Each author made significant individual contributions to this manuscript. PDA, PJC, MNSOJ, CETC, and TLBF: substantial contributions to the concept, design of the work, acquisition and interpretation of the data for the work, writing the manuscript, and final approval of the version of the manuscript to be published. CEV: interpreting the data for the work, writing the manuscript, final approval of the version of the manuscript to be published. CETC and TLBF critical review of its intellectual content.

\section{REFERENCES}

1. Naser N, Ali A, Macadam P. Physical and physiological demands of futsal. J Exerc Sci Fit. 2017;15(2):76-80.

2. Weineck, J. Biologia do esporte. 7nd ed. São Paulo: Manole; 2005.

3. Yüksel Y, Hekim M, Tokgoz M, Zengin S, Ulukan H, Kaya E. Plyometric exercising of athletes at adolescence period. J Hum Sci. 2016;13(3):5602-12.

4. Ramírez-Campillo R, Gallardo F, Henriquez-Olguín C, Meylan CMP, Martínez C, Álvarez C, et al. Effect of vertical, horizontal, and combined plyometric training on explosive, balance, and endurance performance of young soccer players. J Strength Cond Res. 2015;29(7):1784-95.

5. Jayanthi N, Pinkham C, Dugas L, Patrick B, Labella C. Sports specialization in young athletes: evidencebased recommendations. Sports Health. 2013;5(3):251-7.

6. Chipkevitch E. Avaliação clínica da maturação sexual na adolescência. J Pediatric (Rio J). 2001;77 (Suppl 2):S135-42

7. Sayer TA, Hinman RS, Fortin K, Paterson KL, Bennell KL, Timmi A, et al. Differences in hip and knee running moments across female pubertal development. Med Sci Sports Exerc. 2018;50(5):1015-20.

8. Malina RM, Bouchard C, Bar-Or O. Growth, maturation, and physical activity, Human Kinetics. 2nd ed. Champaign: Human Kinetics; 2004
9. Doncaster G, Iga J, Unnithan V. Assessing differences in cardiorespiratory fitness with respect to maturity status in highly trained youth soccer players. Pediatric Exerc Sci. 2018;30(2):216-28.

10. Mortatti AL, Honorato RC, Moreira A, Arruda M. O uso da maturação somática na identificação morfofuncional em jovens jogadores de futebol. Rev Andal Med Deporte. 2013;6(3):108-14.

11. Figueiredo AJ, Golçalves CE, Coelho e Silva MJ, Malina RM. Youth soccer players, 1114 years: maturity, size, function, skill and goal orientation. Ann Hum Biol. 2009;36(1):60-73.

12. Deprez D, Buchheit M, Fransen J, Pion J, Lenoir M, Philipphaerts RM, et al. A longitudinal study investigating the stability of anthropometry and soccer-specific endurance in pubertal high-level youth soccer players. J Sports Sci Med. 2015;14(2):418-26.

13. Philippaerts RM, Vaeyens R, Janssens M, Van Renterghem B, Matthys D, Craen R, et al. The relationship between peak height velocity and physical performance in youth soccer players. J Sports Sci. 2006;24(3):221-30.

14. Perroni F, Pintus A, Frandino M, Guidetti L, Baldari C. Relationship among repeated sprint ability, chronological age, and puberty in young soccer players. J Strength Cond Res. 2018;32(2):364-71.

15. Meyers RW, Oliver JL, Hughes MG, Lloyd RS, Cronin JB. New insights into the development of maximal sprint speed in male youth. J Strength Cond Res. 2017;39(2):2-10. 
16. Gorostiaga EM, Llodio I, Ibáñez J, Granados C, Navarro I, Ruesta M, et al. Diferences in physical fitness among indoor and outdoor elite male soccer players. Eur J Appl Physiol. 2009;106(4):483-91.

17. Álvarez JC, D'Ottavio S, Vera JG, Castagna C. Aerobic fitness in futsal players of different competitive level. J Strength Cond Res. 2009;23(7):2163-6.

18. Barbero-Alvarez JC, Soto VM, Barbeiro-Alvarez V, Granda-Vera J. Match analysis and heart rate of futsal players during competition. J Sports Sci. 2008; 26:(1):63-73.

19. Dogramaci SN, Watsford ML. A Comparasion of two different methods for time motion analysis in team sports. Int J Perform Anal Sport. 2006;6(1):73-83.

20. Gallahue DL, Ozmun JC, Goodway JD. Compreendendo o desenvolvimento motor: bebês, crianças, adolescentes e adultos. 7 ed. Porto Alegre: AMGH; 2013.

21. Rodríguez-Rosell D, Torres-Torrelo, J, Franco-Márquez F, González-Suarez JM, González-Badillo $\mathrm{JJ}$. Effects of light-load maximal lifting velocity weight training vs. combined weight training and plyometrics on sprint, vertical jump and strength performance in adult soccer players. J Sci Med Sport. 2017; 20(7):695-99.

22. Torres-Torrelo J, Rodríguez-Rosell D, González-Badillo J. Light-load maximal lifting velocity full squat training program improves important physical and skill characteristics in futsal players. J Sports Sci. 2017;35(10):967-75

23. Keiner M, Sander A, Wirth K, Schmidbleicher D. Is there a difference between active and less active children and adolescents in jump performanace? J Strength Cond Res. 2013;27(60):1591-6.

24. Negra $Y$, Chaabene $H$, Hachana $Y$, Granacher U. Effects of high-velocity resistance training on athletic performance in prepuberal male soccer athletes. JStrength Cond Res. 2016a;30(12):3290-7.

25. Negra Y, Chaabene H, StoggI T, Hammami M, Chelly MS, Hachana Y. Effectiveness and time-course adaptation of resistance training vs. plyometric training in prepubertal soccer players. J Sport Health Sci. 2016b;30:1-8.

26. Mclellan CP, Lovell DI, Gass GC. The role of rate of force development on vertical jump performance. $J$ Strength Cond Res. 2011;25(2):379-85.

27. Hammami R, Granacher U, Pizzolato F, Chaoauchi M, Chtara M, Behm DG, et al. Associations between change of direction, balance, speed, and muscle power in prepubescent soccer players. J Athl Enhanc. 2017;6(6):1-6.

28. Komi PV, Bosco C. Utilization of stored elastic energy in leg extensor muscles by men and women. Med Sci Sports. 1978;10(4):261-5.

29. Salles A, Baltzopoulos V, Rittweger J. Differential effects of countermovement magnitude and volitional effort on vertical jumping. Eur J Appl Physiol. 2011;111(3):441-8.

30. Cronin JB, Hansen KT. Strength and power predictors of sports speed. J Strength Cond Res. 2005;19(2):349-57.

31. van Hooren B, Zolotarjova J. The difference between countermovement and squat jump performances: a review of underlying mechanisms with practical applications. J Strength Cond Res. 2017;31(7):2011-20

32. Alexander RM. Tendon elasticity and muscle function. Comp Biochem Physiol A Mol Integr Physiol. 2002;133(4):1001-11.

33. Marques MC, Gabbett TJ, Marinho DA, Blazevich AJ, Sousa A, van den Tillaar R, et al. Influence of strength, sprint running, and combined strength and sprint running training on short sprint performance in young adults. Int J Sports Med. 2015;36(10):789-95.

34. Vescovi JD, McGuigan MR. Relationships between sprinting, agility, and jump ability in female athletes. J Sports Sci. 2008;26(1):97-107.

35. Roberts TJ, Konow N. How Tendons buffer energy dissipation by Muscle. Exerc Sports Sci Rev. 2013;41(4):186-93

36. Enoka RM. Bases neuromecânicas da cinesiologia. 2 ed. São Paulo: Manole; 2000.

37. Nakamura FY, Pereira LA, Rabelo FN, Ramirez-Campillo R, Loturco I, et al. Faster futsal players perceive higher training loads and present greater decreases in sprinting speed during the preseason. $J$ Strength Cond Res. 2016;30(6):1553-62.
38. Wisloff U, Castagna C, Helgerud J, Jones R, Hoff J. Strong correlation of maximal squat strength with sprint performance and vertical jump height in elite soccer players. Br J Sports Med. 2004;38(3):285-8.

39. Brughelli M, Cronin J, Levin G, Chaouachi A. Understanding change of direction ability in sport: a review of resistance training studies. Sports Med. 2008; 38(12):1045-63.

40. Mackala K, Fostiak M, Kowalski K. Selected determinants of acceleration in the $100 \mathrm{~m}$ sprint. J Hum Kinet. 2015;45:135-48.

41. Meyers RW, Oliver JL, Hughes MG, Lloyd RS, Cronin JB. Influence of age, maturity, and body size on the spatiotemporal determinants of maximal sprint speed in boys. J Strength Cond Res. 2017;31(4):1009-16.

42. Comfort P, Stewart A, Bloom L, Clarkson B. Relationships between strength, sprint, and jump performance in well-trained youth soccer players. J Strength Cond Res. 2014;28(1):173-7.

43. Ferreira MN, Mateus JR, Mateus S, Costa GC. A influência da atividade física e esportes sobre o crescimento e a maturação. Rev Bras Fut Futsal. 2015;7(24):237-43.

44. Granados A, Gebremariam A, Lee JM. Relationship between timing of peak height velocity and pubertal staging in boys and girls. J Clin Res Pediatr Endocrinol. 2015;7(3):235-7.

45. Phillip M, Lazar L. The regulatory effect of hormones and growth factors on the pubertal growth spurt. Endocrinology. 2003;13(6):459-65.

46. Hansen L, Bangsbo J, Twisk J, Klausen K. Development of muscle strength in relation to training level and testosterone in young male soccer players. J Appl Physiol (1985). 1999;87(3):1141-7.

47. Oliver JL, Lloyd RS, Rumpf MC. Developing speed throughout childhood and adolescence: the role of growth, maturation and training. J Strength Cond. 2013;35(3):42-8.

48. Meyers RW, Oliver JL, Hughes MG, Cronin JB, Lloyd RS. Maximal sprint speed in boys of increasing maturity. Pediatr Exerc Sci. 2015;27(1):85-94

49. Fernandez-Gonzalo R, De Souza-Texeira F, Bresciani G, Garcia-López D, Hernandez-Murúa JA, Jiménez -Jiménez $\mathrm{R}$, et al. Comparison of technical and physiological characteristics of prepubescent soccer players of different ages. J Strength Cond Res. 2010;24(7):1790-8.

50. Read P, Meyers RW, Lloyd RS, Hughes MG, Cronin JB, Oliver JL. The impact of peak height velocity on changes in sprint kinetics and kinematics in boys. In: National Strength and Conditioning Association (NSCA) 39th National Conference. New Orleans, LA; 2016

51. Laffaye G, Choukou MA, Benguigui N, Padulo J. Age- and gender-related development of stretch shortening cycle during a sub-maximal hopping task. Biol Sport. 2016;33(1):29-35.

52. Radnor JM, Oliver JL, Waugh CM, Myer GD, Moore IS, Lloyde RS. The influence of growth and maturation on stretch-shortening cycle function in youth. 2018;48(1):57-71.

53. Korff T, Horne SL, Cullen SJ, Blazevich AJ. Development of lower limb stiffness and its contribution to maximum vertical jumping power during adolescence. J Exp Biol. 2009;212(Pt 22):3737-42.

54. Kubo K, Kanehisa H, Kawakami Y, Fukanaga T. Growth changes in the elastic properties of the human tendon structures. Int J Sports Med. 2001;22(2):138-43.

55. Wang $L I$, Lin DC, Huang C. Age effect on jumping techniques and lower limb stiffness during vertica jump. Res Sports Med. 2004;12(3):209-19.

56. Gajdosik RL. Passive extensibility of skeletal muscle: review of the literature with clinical implications. Clin Biomech (Bristol, Avon). 2001;16(2):87-101.

57. Nakagawa Y, Majima T, Nagashima K. Effect of ageing on ultrastructure of slow and fast skeletal muscle tendon in rabbit Achilles tendons. Acta Physiol Scand. 1994;152(3):307-13.

58. Kubo K, KawakamiY, Fukunaga T. Influence of elastic properties of tendon structures on jump performance in humans. J Appl Physiol (1985). 1999;87(6): 2090-6.

59. Luebbers PE, Potteiger JA, Hulver MW, Thyfault JP, carper MJ, Lockwood RH. Effects of plyometric training and recovery on vertical jump performance and anaerobic power. J Strength Cond Res. 2003;17(4):704-9.

60. Söhnlein Q, Müller E, StögglTL. The effect of 16-week plyometric training on explosive actions in early to mid-puberty elite soccer players. J Strength Cond Res. 2014;28(8):2105-14. 